This item was submitted to Loughborough's Research Repository by the author.

Items in Figshare are protected by copyright, with all rights reserved, unless otherwise indicated.

\title{
Oil booms, bank productivity and natural resource curse in finance
}

PLEASE CITE THE PUBLISHED VERSION

PUBLISHER

Elsevier BV

VERSION

AM (Accepted Manuscript)

PUBLISHER STATEMENT

This paper was accepted for publication in the journal Economics Letters and the definitive published version is available at https://doi.org/10.1016/j.econlet.2019.07.002.

LICENCE

CC BY-NC-ND 4.0

\section{REPOSITORY RECORD}

Adetutu, Morakinyo O, Kayode Odusanya, John E Ebireri, and Victor Murinde. 2019. "Oil Booms, Bank Productivity and Natural Resource Curse in Finance”. figshare. https://hdl.handle.net/2134/9801785.v1. 


\section{Introduction}

An emerging idea in the finance literature ${ }^{1}$ is that the low levels of financial development in commodity-based economies is a consequence of their natural resource abundance ${ }^{2}$ A few earlier works (Beck, 2011; Bhattacharyya and Hodler, 2014) provide some indication of a natural resource curse in financial sectors of resource-rich economies, based on the macro-level relationship between financial development indicators (e.g. private credit to GDP ratio) and resource dependence (e.g. commodity rents). However, there are concerns about (i) the challenge of disentangling the impact of resource dependence on the financial system from those of other aggregates, and (ii) the likely endogeneity of resource dependence measures (Beck and Poelhekke, 2017). Even when microeconometric evaluations on the impact of resource dependence on bank-level performance indicators have attempted to address the above concerns, the results are inconclusive (Beck, 2011; Beck and Poelhekke, 2017) ${ }^{3}$ This is potentially due to two issues.

First, the microeconomic studies are based on a range of bank performance measures which do not provide compelling empirical evidence. For instance, Beck (2011) used different indicators on bank business strategy, cost-income ratios and bank stability, while Beck and Poelhekke (2017) employed deposit and loan measures. Across both studies, the impact of resource dependence on bank-level performance is either statistically insignificant or contradictory across indicators. Second, the studies rely on annual data, which may not adequately capture commodity market dynamics. Commodity markets are notoriously volatile and their effects on financial markets can be short-lived, hence higher frequency data might be crucial in capturing these dynamics (Faust et al., 2004; Ferraro et al., 2015).

\footnotetext{
${ }^{1}$ See Beck (2016) for a review.

${ }^{2}$ A large literature explains the poor economic performance of resource-dependent countries under the Dutch disease phenomenon (Corden and Neary, 1982), which refers to the adverse effect of natural resource booms on the tradable sector.

${ }^{3}$ To our knowledge, only these two papers fall into this category.
} 
Thus, this letter employs total factor productivity (TFP) as a measure of bank performance. We believe that TFP offers a more comprehensive and robust measure of firm-level performance. Further, we use a rich monthly micro dataset on the Kazakh banking sector, which allows us to more precisely account for oil market volatility. The Kazakh banking sector offers an interesting case study on financial natural resource curse. It is a major oil producer that accounts for $1.8 \%$ of global oil reserves (BP, 2017), with the oil sector contributing over $60 \%$ to total exports (World Bank, 2018). However, despite posting comparable growth credentials as the East Asian tigers, it has experienced its fair share of boomrelated financial crises (IMF, 2001; Glass et al., 2014). Our research therefore contributes to the literature by being the first to provide concrete evidence on the potential impact of natural resources on bank-level productivity as an axiom of the natural resource curse.

\section{Data}

We construct a database on banking and oil price variables from January 2008 to October 2017 using information from the National Bank of Kazakhstan (NBK) and the Energy Information Administration (EIA). The banking data combines publicly-available and restricted-use information on bank financials, obtained from the Research Department of the NBK.

\subsection{Bank-level TFP}

Total factor productivity (TFP) is derived from the production function specification:

$$
y_{i t}=\alpha+\beta_{1} k_{i t}+\beta_{2} l_{i t}+\beta_{3} m_{i t}+\omega_{i t}+\varepsilon_{i t}
$$

where $y_{i t}$ is the $\log$ of output of bank $i$ in period $t$, represented by the sum of loans and investment securities. $k_{i t}$ is the log of the state input (capital), given by fixed assets; $l_{i t}$ is the log of free/variable input (labour), represented by wages. $m_{i t}$ is the log of intermediate input which we proxy with total deposits. 
$\omega_{i t}$ is the unobservable productivity and $\varepsilon_{i t}$ captures white noise. We assume that $\omega_{i t}$ evolves following a first-order Markov process:

$$
\omega_{i t}=E\left(\omega_{i t} \mid \omega_{i t-1}\right)+u_{i t}
$$

where $u_{i t}$ is a random component. We compute $\omega_{i t}$ following the procedure proposed by Ackerberg et al. (2015), which overcomes the simultaneity bias that could arise from the potential correlation between the banks observable inputs and $\omega_{i t}$. Under this procedure, we use the inverse demand function for the proxy variable, along with other model parameters, to obtain the residuals $\omega_{i t}$.

\subsection{Defining oil boom}

Our main independent variable captures episodes of oil price booms in any period $t$ : boom $_{t}$, which we derive as an indicator variable that assumes the value of 1 if actual oil prices exceed expected prices, and zero otherwise. We use real monthly spot prices and real oil futures as proxies for actual and expected prices, respectively. The rationale for using oil futures as a measure of market expectations is that they embody market operators best views or rational expectations about future spot prices (Wu and McCallum, 2005; Hamilton, 2009).

By employing an oil price boom variable, we bypass the endogeneity problems in traditional resource rent measures by parsing out (and using) the exogenous international oil price component from the endogenous resource extractioninduced component. This approach seems justified in the Kazakhstan context as we find the exogenous oil price swings over the study period to be the main driver of oil rents in the face of stable oil production (see Fig. A1 in the online appendix). Table 1 contains the summary statistics of our key variables. See online appendix for a detailed description of all variables in this paper. 
Table 1: Descriptive statistics

\begin{tabular}{cccccc}
\hline \hline Variable & Obs. & Mean & Std Dev. & Min. & Max. \\
\hline TFP (logs) & 2357 & 16.680 & 1.830 & 9.268 & 19.826 \\
Boom (dummy) & 118 & 0.421 & 0.494 & 0 & 1 \\
\hline
\end{tabular}

\section{Econometric framework}

To gauge the relationship between bank productivity and oil booms, we fit the following model:

$$
T F P_{i t}=\alpha_{i}+\alpha_{t}+\beta_{i} t+\delta_{1} \text { boom }_{t}+\delta_{2} X_{i t-2}+\delta_{3} \text { activity }_{t-2}+v_{i t}
$$

where $T F P_{i t}$ is bank-level total factor productivity, the bank dummies $\alpha_{i}$ capture any time-invariant characteristics that may influence bank performance; $\alpha_{t}$ are time dummies that control for the impact of monetary policy, economic, political events etc., occurring at the national and global level; $\beta_{i} t$ are bank-specific trends to capture the slow-moving effects of technological progress, human capital development, etc., which may evolve at different rates across banks. boom ${ }_{t}$ is the oil boom variable defined in section 2.2. To ensure that $\delta_{1}$ captures the impact of the boom, rather than other contemporaneous characteristics, we include $X_{i t-2}$, a vector of bank-level characteristics such as age, size and ownership. These controls are lagged $t-2$ to mitigate any potential endogeneity problems. We also capture the level of economic activity using the monthly investment activity index, activityt-2. $v_{i t}$ is an idiosyncratic error term.

\section{Empirical results}

Table 2 reports the results of the TFP regressions. In column 1, we regress TFP on the oil boom variable without any control variables. We find a strong negative effect of oil booms on bank TFP, which indicates that during oil booms, bank-level TFP declined by $79 \%$ on average. This effect is significant at the $1 \%$ 
level. In column 2, we add bank-level characteristics and the economic activity variable. The estimated boom coefficient drops in magnitude but remains statistically significant at $1 \%$. The impact of bank age on TFP is negative and significant at the 10\%-level, while bigger and foreign owned banks are found to have higher levels of productivity, albeit the latter is not statistically significant at conventional levels. In column 3, we go beyond establishing the effect of oil boom on bank performance by further exploring whether bank performance during commodity booms is an axiom of the natural resource curse in finance.

\begin{tabular}{cccc}
\multicolumn{4}{c}{ Table 2: Baseline results } \\
\hline \hline Dep var.: TFP & 1 & 2 & 3 \\
\hline boom $_{t}$ & $-0.797^{* * *}$ & $-0.597^{* * *}$ & $-0.383^{* * *}$ \\
& {$[0.158]$} & {$[0.108]$} & {$[0.126]$} \\
size $_{i t-2}$ & & $0.448^{* * *}$ & $0.475^{* * *}$ \\
& & {$[0.043]$} & {$[0.041]$} \\
age $_{\text {it-2 }}$ & & $-1.529^{*}$ & $-1.635^{*}$ \\
& & {$[0.911]$} & {$[0.913]$} \\
foreign $_{i t-2}$ & & 0.035 & 0.025 \\
& & {$[0.049]$} & {$[0.048]$} \\
activity $_{i t-2}$ & & 0.559 & 0.617 \\
& & {$[1.128]$} & {$[1.109]$} \\
boom $_{t} \times$ FCY & & & $-0.907^{* * *}$ \\
& & & {$[0.248]$} \\
\hline R-squared & 0.844 & 0.886 & 0.887 \\
Wald/F-test & 0.000 & 0.000 & 0.000 \\
Bank FE & Yes & Yes & Yes \\
Period FE & Yes & Yes & Yes \\
Bank-specific trend & Yes & Yes & Yes \\
Observations & 2357 & 2303 & 2303 \\
\hline
\end{tabular}

Notes: OLS regressions. Robust standard errors in parenthesis. Clustering at the bank-level does not qualitatively affect results. $* *, * *, \& *$ indicate significance at $1,5 \& 10 \%$-level, respectively.

In the seminal theoretical treatment of natural resource curse, adverse exchange rate effect is highlighted as an important channel through which commodity booms impact economic performance (Corden and Neary, 1982). Meanwhile, a related channel for the financial sector is that windfalls from abroad often lead to episodes of excessive foreign capital (Benigno and Fornaro, 2014). 
Kazakh banks are particularly known to demonstrate a strong preference for foreign investments and assets during episodes of abundant foreign currency (IMF, 2005; Glass et al., 2014). Given the foregoing, we depict this foreign asset channel by adding to our specification an interaction term between the oil boom variable and foreign loan exposure: $b_{o o m} \times F C Y_{i t-2}$, where $F C Y$ is the ratio of foreign currency lending to total lending.

Column 3 contains the results from the augmented regression. The coefficient on the boom variable remains statistically significant at $1 \%$, indicating a $38 \%$ decline in TFP. The interaction coefficient is also negative and significant at $1 \%$, suggesting that higher foreign currency exposure further decreases bank productivity during commodity booms. This finding seems consistent with the Dutch disease postulation on the detrimental effect of boom-related currency effects on economic performance. Moreover, it is well-documented that the excessive risks associated with increased foreign currency exposure during episodes of economic booms, have led to severe financial crises in the Kazakh baking sector (Glass et al., 2014).

\subsection{Robustness checks}

We conduct two robustness exercises. First, we check the sensitivity of our results to the TFP measurement by constructing an alternative TFP measure following the Levinsohn and Petrin (2003) procedure. We then re-estimate all the models in Table 2 using this alternative TFP measure. The results from these models, which are presented in Table 3, are qualitatively analogous to our baseline results and main conclusions. Second, because our panel is not strongly balanced there is potential for endogeneity of attrition (Hopenhayn, 1992; Farinas and Ruano, 2005). To this end, we further employ a TFP measure that accounts for firm attrition by treating productivity as a function of its past values and a survival indicator (Olley and Pakes, 1996; Rovigatti and Mollisi,

\footnotetext{
${ }^{4}$ Due to mergers and acquisitions, there is a non-random exit of a few banks from our sample. It is therefore conceivable that less productive banks exit the banking industry, leaving only the most productive banks in the sample.
} 
2018). The results obtained from the attrition-corrected TFP measures are presented in Table 4. We find that attrition does not qualitatively affect our conclusion that bank productivity in the Kazakh banking sector is lower during oil booms.

\begin{tabular}{|c|c|c|c|}
\hline Dep var.: TFP & 1 & 2 & 3 \\
\hline boom $_{t}$ & $\begin{array}{c}-0.663^{* * *} \\
{[0.151]}\end{array}$ & $\begin{array}{c}-0.563^{* * *} \\
{[0.107]}\end{array}$ & $\begin{array}{c}-0.358^{* * *} \\
{[0.126]}\end{array}$ \\
\hline$s_{i z} e_{i t-2}$ & & $\begin{array}{c}0.362^{* * *} \\
{[0.042]}\end{array}$ & $\begin{array}{c}0.387^{* * *} \\
{[0.041]}\end{array}$ \\
\hline$a g e_{i t-2}$ & & $\begin{array}{c}-1.602^{*} \\
{[0.909]}\end{array}$ & $\begin{array}{c}-1.703^{*} \\
{[0.911]}\end{array}$ \\
\hline foreign $_{i t-2}$ & & $\begin{array}{c}0.036 \\
{[0.052]}\end{array}$ & $\begin{array}{c}0.026 \\
{[0.051]}\end{array}$ \\
\hline activity $_{i t-2}$ & & $\begin{array}{c}0.010 \\
{[0.010]}\end{array}$ & $\begin{array}{c}0.010 \\
{[0.010]}\end{array}$ \\
\hline boom $_{t} \times F C Y_{i t-2}$ & & & $\begin{array}{c}-0.864^{* * *} \\
{[0.251]}\end{array}$ \\
\hline R-squared & 0.851 & 0.863 & 0.865 \\
\hline Wald/F-test & 0.000 & 0.000 & 0.000 \\
\hline Bank FE & Yes & Yes & Yes \\
\hline Period FE & Yes & Yes & Yes \\
\hline Bank-specific trend & Yes & Yes & Yes \\
\hline Observations & 2357 & 2303 & 2303 \\
\hline
\end{tabular}

Notes: OLS regressions. Robust standard errors in parenthesis. Clustering at the bank-level does not qualitatively affect results. $* *, * *, \& *$ indicate significance at $1,5 \& 10 \%$-level, respectively.

\section{Conclusion}

This note sheds new light on the existence of a natural resource curse in the financial sector of commodity-exporting economies. Using microeconomic data from the Kazakh banking sector, we find a significant decline in banks' TFP during episodes of oil booms and this negative impact is more pronounced for the banks with greater foreign currency exposure. Our results suggest that poor bank productivity during resource booms is an axiom of the natural resource curse. 
Table 4: Re-estimations accounting for bank attrition

\begin{tabular}{cccc}
\hline \hline Dep var.: TFP & 1 & 2 & 3 \\
\hline boom $_{t}$ & $-0.662^{* * *}$ & $-0.562^{* * *}$ & $-0.354^{* * *}$ \\
& {$[0.150]$} & {$[0.108]$} & {$[0.126]$} \\
size $_{\text {it-2 }}$ & & $0.363^{* * *}$ & $0.388^{* * *}$ \\
age $_{\text {it-2 }}$ & & {$[0.042]$} & {$[0.041]$} \\
& & $-1.594^{*}$ & $-1.694^{*}$ \\
foreign $_{\text {it-2 }}$ & & {$[0.909]$} & {$[0.911]$} \\
& & 0.035 & 0.026 \\
activity $_{i t-2}$ & & {$[0.051]$} & {$[0.050]$} \\
& & 0.010 & 0.010 \\
boom $_{t} \times$ FCY & & {$[0.010]$} & {$[0.010]$} \\
& & & $-0.865^{* * *}$ \\
R-squared & & & {$[0.250]$} \\
Wald/F-test & 0.000 & 0.000 & 0.000 \\
Bank FE & Yes & Yes & Yes \\
Period FE & Yes & Yes & Yes \\
Bank-specific trend & Yes & Yes & Yes \\
Observations & 2357 & 2303 & 2303 \\
\hline
\end{tabular}

Notes: OLS regressions. Robust standard errors in parenthesis. Clustering at the bank-level does not qualitatively affect results. $* *, * *, \& *$ indicate significance at $1,5 \& 10 \%$-level, respectively.

\section{References}

[1] Ackerberg, D., K. Caves, and G. Frazer., 2015. Identification Properties of Recent Production Function Estimators. Econometrica, 83(6): 24112451

[2] Beck, T., 2011. Finance and oil: Is there a natural resource curse in financial development? In: Rabah Arezki, Thorvaldur Gylfason and Amadou Sy (Eds.): Beyond the Curse: Policies to Harness the Power of Natural Resources, Washington DC: IMF, pp.81-106.

[3] Beck, T., 2016. Finance, institutions and development: Literature survey and research agenda. EDI working paper series WP16/7.

[4] Beck, T. and Poelhekke, S., 2017. Follow the money: Does the financial sector intermediate natural resource windfalls? De Nederlandsche Bank Working 
Paper No. 545.

[5] Benigno, G. and Fornaro, L., 2014. The financial resource curse. The Scandinavian Journal of Economics, 116(1), pp.58-86.

[6] Bhattacharyya, S. and Hodler, R., 2014. Do natural resource revenues hinder financial development? The role of political institutions. World Development, 57, pp.101-113.

[7] BP, 2017. Statistical Review of World Energy. www.bp.com/statisticalreview. [8] Corden, W.M. and Neary, J.P., 1982. Booming sector and de-industrialisation in a small open economy. The Economic Journal, 92(368), pp.825-848.

[9] Farinas, J.C. and Ruano, S., 2005. Firm productivity, heterogeneity, sunk costs and market selection. International Journal of Industrial Organization, 23(7-8), pp.505-534.

[10] Faust, J., Swanson, E.T. and Wright, J.H., 2004. Identifying VARs based on high frequency futures data. Journal of Monetary Economics, 51(6), pp.11071131.

[11] Ferraro, D., Rogoff, K. and Rossi, B., 2015. Can oil prices forecast exchange rates? An empirical analysis of the relationship between commodity prices and exchange rates. Journal of International Money and Finance, 54, pp.116-141.

[12] Hamilton, J.D., 2009. Causes and consequences of the oil shock of 2007-08. Brookings Papers on Economic Activity, 40(1), pp. 215-259.

[13] Hopenhayn, H.A., 1992. Entry, exit, and firm dynamics in long run equilibrium. Econometrica: Journal of the Econometric Society, 60(5), pp.1127-1150.

[14] IMF (2001) Republic of Kazakhstan, IMF Staff Country Report No. 01/20, IMF, Washington, DC.

[15] IMF (2005) Republic of Kazakhstan: selected issues, IMF Staff Country Report No. 05/240, IMF, Washington, DC

[16] Levinsohn, J., and Petrin, A., 2003. Estimating Production Functions Using Inputs to Control for Unobservables. The Review of Economic Studies 70(2), pp. 317-341.

[17] Olley, S. G. and Pakes, A., 1996. The dynamics of productivity in the telecommunications equipment industry, Econometrica, 64(6), pp. 12631297 
[18] Rovigatti, G. and V. Mollisi, 2018. Theory and practice of total-factor productivity estimation: The control function approach using Stata. The Stata Journal, 18(3), pp. 618662

[19] World Bank (2018). World Development Indicators, Washington: The World Bank

[20] $\mathrm{Wu}, \mathrm{T}$. and McCallum, A., 2005. Do oil futures prices help predict future oil prices? FRBSF Economic Letter No. 2005-38. 